University of Northern lowa

UNI ScholarWorks

Spring 2013

\title{
Social Studies Content Reading about the American Revolution Enhanced with Graphic Novels
}

Kari Bosma

Ankeny (lowa) Community School District

Audrey C. Rule

University of Northern lowa

See next page for additional authors

Let us know how access to this document benefits you

Copyright (C2013 Social Studies Research and Practice. The copyright holder has granted permission for posting.

Follow this and additional works at: https://scholarworks.uni.edu/ci_facpub

Part of the Curriculum and Instruction Commons

\section{Recommended Citation}

Bosma, Kari; Rule, Audrey C.; and Krueger, Karla K., "Social Studies Content Reading about the American Revolution Enhanced with Graphic Novels" (2013). Curriculum \& Instruction Faculty Publications. 16. https://scholarworks.uni.edu/ci_facpub/16

This Article is brought to you for free and open access by the Faculty Work at UNI ScholarWorks. It has been accepted for inclusion in Curriculum \& Instruction Faculty Publications by an authorized administrator of UNI ScholarWorks. For more information, please contact scholarworks@uni.edu. 


\section{Authors}

Kari Bosma, Audrey C. Rule, and Karla K. Krueger

This article is available at UNI ScholarWorks: https://scholarworks.uni.edu/ci_facpub/16 


\title{
Social Studies Content Reading about the American Revolution Enhanced with Graphic Novels
}

\author{
Kari Bosma \\ Ankeny (IA) Community School District \\ Audrey C. Rule \\ Karla S. Krueger \\ University of Northern Iowa
}

Graphic novels can contribute to effective content area reading on social studies topics such as the American Revolution. This action research study's purpose was to examine student recall of facts, enjoyment of reading, and interest in the topic when using graphic novels as compared to illustrated nonfiction prose in social studies content area reading. Twenty-two fifth grade students (13 females, 9 males) in a public school in a Midwestern state participated in the study. Half of the students read about the Boston Massacre and Patrick Henry through graphic novels and read about Paul Revere and the Boston Tea Party with illustrated nonfiction texts, with the other half doing the opposite. The mean number of correct ideas recalled by students two weeks after reading two books in the graphic novel condition was 8.6 compared to 7.1 for the nonfiction prose condition with a medium effect size. Students rated their reading enjoyment significantly higher in the graphic novel condition indicating that graphic novels should be employed more often into the school curriculum. Suggestions for integrating graphic novels into the curriculum are provided along with other ways to take action.

Keywords: action research, social studies content reading, graphic novels, American Revolution, student engagement, elementary students

\section{Introduction}

Graphic novels are growing in popularity (Griffith, 2010; MacDonald, 2004; Serchay, 2008). Graphic novels have developed (Serchay, 2008): from the use of pictures to tell stories on cave walls; to the first use of the term graphic novel in a 1964 article; and then to the first book listed as a graphic novel in 1978. Sales of graphic novels have increased, even during an economic downturn, noted Paula Griffith (2010), signaling their movement into pop culture. She further stated recent movies, toys, and video games have been based on graphic novels, and several major literary awards have honored graphic novels. Beyond popularity, research shows graphic novels are associated with increasing vocabulary development for children, attracting reluctant readers, and supporting English language learners (Serchay, 2008). Setting aside counter arguments that graphic novels are not real literature, school librarians and teachers have begun focusing on issues of curricular use and quality. An extensive listing of evaluation criteria, found in Griffith's research, confirms teachers and librarians hold graphic novels to the same high quality literary standards used for evaluation of all fiction (such as three-dimensional characters, themes relevant to readers, conflict appropriate for readers) as well as for nonfiction, such as a useful table of contents and index, organization that aids comprehension, and "information interesting enough to keep readers actively engaged with the text" (Griffith, 2010, p. 184). Griffith's criteria specific to graphic novels stress characteristics such as: the 
arrangement of illustrations "in a way that readers can easily follow the sequence;" gutters that "aid comprehension;" the appropriateness of artistic style for the story; and illustrations' clues to emotion and mood (p. 183). Further, H.W. Wilson's (2011) Core Collections, which serves as an aid to librarians for identifying the highest quality literature to purchase, has recently added the Graphic Novels Core Collection, a database with descriptive and evaluative annotations for over 2,000 recommended graphic novels.

This study describes how a school librarian (officially titled "teacher librarian" in the state in which the study was conducted because this professional is certified to teach as well as assist students in using library media) supported social studies content learning and literacy using nonfiction graphic novels and illustrated nonfiction texts in lessons in which fifth grade students engaged in reading about important persons and events of the American Revolution. This study investigates the use of graphic novels compared to traditional nonfiction texts in fifth graders' study of concepts related to this historic event. It further assesses students' interest in the topic and enjoyment of reading through this comparison.

\section{Graphic Novels in Content Area Reading}

\section{Literature Review}

Graphic novels, as distinguished from comic strips or comic books, are longer works that have continuing characters and plots (Bruggeman, 1997), just as a prose novel. Despite some claims that graphic novel is used to remove the stigma of the label comic book, Serchay (2008), supported a definition of graphic novels as bound books of either fiction or nonfiction written in the comic book format, not to include books that reprint comic strips such as a Peanuts collection nor easy-reader books with word balloons such as Mo Willems books. Often associated with graphic novels, manga are Japanese "printed comics found in graphic-novel format" (Schwartz \& Rubinstein-Avila, 2006). The related Japanese art form, anime, consists of animated cartoons often derived from movies or television, printed in books using word balloons to show the dialogue. Today's Generation Y students (born between 1982-2003) are thought to often desire constant visual stimulation to maintain attention; graphic novels meet this need (Short \& Reeves, 2009). Heidi MacDonald (2004), a librarian, found the popularity of graphic novels with teenagers motivated many to visit the library with or without special promotional events.

James Carter (2007) proposed graphic novels be used to "expose injustice and examine complex social issues" (p. 51). Certainly, the current study's topic, the American Revolution, constitutes a complex social justice issue. One approach recommended by Carter is collaboration among teachers of different disciplines in the use of graphic novels. In the current study, a school librarian teamed with a fifth grade teacher to support learning about the American Revolution through reading graphic novels and informational books. As Carter advocated, these school library texts were used as a supplement to the regular social studies textbook titled We the People: Build Our Nation. Important taxation and oppression issues were examined from several viewpoints (colonists, British soldiers, King George III, elementary students) to critically examine motives and consequences.

There are many reasons to use graphic novels in social studies content area reading. Principles of acceptance of diversity are reflected by teachers providing students with a wide range of reading materials reflecting different cultures' modes of literary expression (e.g., 
Japanese manga). Classrooms should move away from a one-sided notion of literacy instruction, recognizing that students need a variety of texts to address their diverse needs, including examining social and democratic issues. Graphic novels provide visual imagery to accompany text, giving visual cues to boost reading comprehension. Emotional subtleties embedded in the text are sometimes more easily interpreted and remembered through facial expressions of the illustrated characters. For example, Gretchen Schwarz (2002) commended the ability of graphic novels to supplant dull textbooks with emotionally-rich, imaginative illustrations such as the empire state building bent in sorrow over the ground zero site. Several popular graphic novels that address social studies topics relevant to middle grades students, suggested by Adam Martin (2009), include: a book that contrasts President Lincoln through historical and contemporary perceptions (McCloud, 1998), and another story of a student's battle with bulimia (Gorman, 2008). Graphic novels often "present alternative views of culture, history, and human life in general in accessible ways, giving voice to minorities and those with diverse viewpoints" (Schwarz , 2002, p. 264). She also noted students may examine the medium of graphic novels by engaging in the following: analyzing the effects of color on emotion; understanding how illustrations can stereotype various groups; evaluating how perspective and view angle affects perception; and by considering how realism and fantasy affect the image's message. Librarians should take the first step by approaching teachers to help them map the ways graphic novels can address curriculum standards (Rudiger \& Schliesman, 2007).

\section{Graphic Novels for Reading Engagement}

One of the few research studies involving graphic novels sought to determine ways freechoice reading of this particular genre would positively impact middle school students (Edwards, 2008, 2009). Edwards noted that the prevalence of video games, cell phones, and MP3 players leave little room for time spent in pleasure reading. Graphic novels, however, were a choice for some students who would not read anything else. Another study (Simmons \& O'Bryant, 2009) was conducted by school librarians to determine what sources of media would increase reading among adolescent male students. The librarians surveyed their male student population, asking what they wished would be included in the media center. The results overwhelmingly indicated that students desired manga and graphic novels. At one middle school, an elective class taking the form of a student book club focused on graphic novels was found to be so popular with students, a waiting list had to be formed (Seyfried, 2008). Reluctant readers who participated in the book club returned to the library for additional graphic novels after completion of the course. Libraries can support the needs of their patrons by building a collection of graphic novels (Rudiger \& Schliesman, 2007). The visual nature of graphic novels assists students with cognitive disabilities and English language learners. Ways to promote graphic novel reading among students (O'English, Matthews, \& Lindsey, 2006) include: displays of new books or holiday reading, creating a web log or wiki where students can post reviews of graphic novels, and providing opportunities to students to create their own graphic novels.

Much has been written recently on using graphic novels with middle school students. Little has been discussed about their use with elementary students. Few research studies concerning the efficacy of graphic novel use have been conducted. The current investigation examines graphic novel use in a social studies content area reading context. 


\section{Multimodal Nature of Graphic Novels}

Graphic novels can engage a variety of readers because of their highly visual format. Unlike typical novels from which readers obtain most of the meaning through the words of the text, graphic novels require the reader to interpret the provided images to understand the story. Students whose reading abilities prevent them from enjoying text-based reading frequently are drawn to graphic novels because they can access the story through a different modality (Lyga \& Lyga, 2004). Graphic novels and comics are often known as "sequential art" because they consist of a set of ordered images that tell the story, appealing to today's students much like film and electronic media. Both text and images are used in complex ways to make meaning: besides using contextual clues, readers must interpret facial expressions, body postures, drawing perspective, tone of voice, and grunts or exclamations. A variety of fonts and script styles are used to express vocalizations with characters sometimes breaking out of their rectangular frames to express their emotions. Because of this complexity, Michael Lavin (1998) proposed that reading graphic novels entails more complex cognitive skills than the reading of text alone.

Taking a perspective from business and advertising, graphic novels constitute "cool" rather than "hot" media because the viewer must use his or her imagination to complete the communication (McLuhan, 1964. p. 36; Short \& Reeves, 2010, p. 418). Hot media, such as a photograph of a bedroom window looking out on a colorful flower garden, provide the observer with a dense amount of visual information, whereas a cartoon may provide only part of a window frame and the suggestion of a landscape beyond requiring the viewer to mentally insert the details. Cool media, therefore, are high in audience participation and engagement.

Although the lines in graphic novels or comics are not perfectly realistic pictures of people or movement, when we look at the lines, we 'see' people who are moving because we participate in the medium using our imaginations to 'fill in the blanks.' In our mind's ear, we may even 'hear' a 'BAM' sound when we see the three letters $b, a$, and $m$ accompanied by a drawing that denotes action (Short \& Reeves, 2010, p. 419). This high level of reader involvement brings enjoyment, maintaining interest in the story. We therefore propose graphic novels in our study will be found to be more highly rated in these aspects (enjoyment and interest) than illustrated novels. We also suggest that graphic novels will assist students in meeting social studies outcomes concerning the American Revolution, as discussed in the next section.

\section{Planned Social Studies Outcomes for Study Participants}

In social studies, a concept is a representation "of a group of objects, people, events, or symbols of two or more members," (Sunal \& Haas, 2011, p. 95) while a generalization "identifies relationships between two or more concepts" (p. 117) especially to explain cause and effect. Generalizations supported by evidence are particularly powerful aspects of social studies learning because they permit prediction and explanation of events. Regarding the American Revolution, some concepts include: colonists, tea party, taxation, and Boston Harbor. The school librarian identified generalizations related to the four chosen topics (Boston Massacre, Boston Tea Party, Patrick Henry, and Paul Revere) that matched state standards and represented important learning outcomes of reading these texts. These are shown in Table 1. Data were collected and analyzed during this study to determine if students acquired the identified key concepts and generalizations and met state standards for social studies education. 
Table 1

School librarian-identified Key Concepts of each Historic Event or Person Connected to State Social Studies Standards

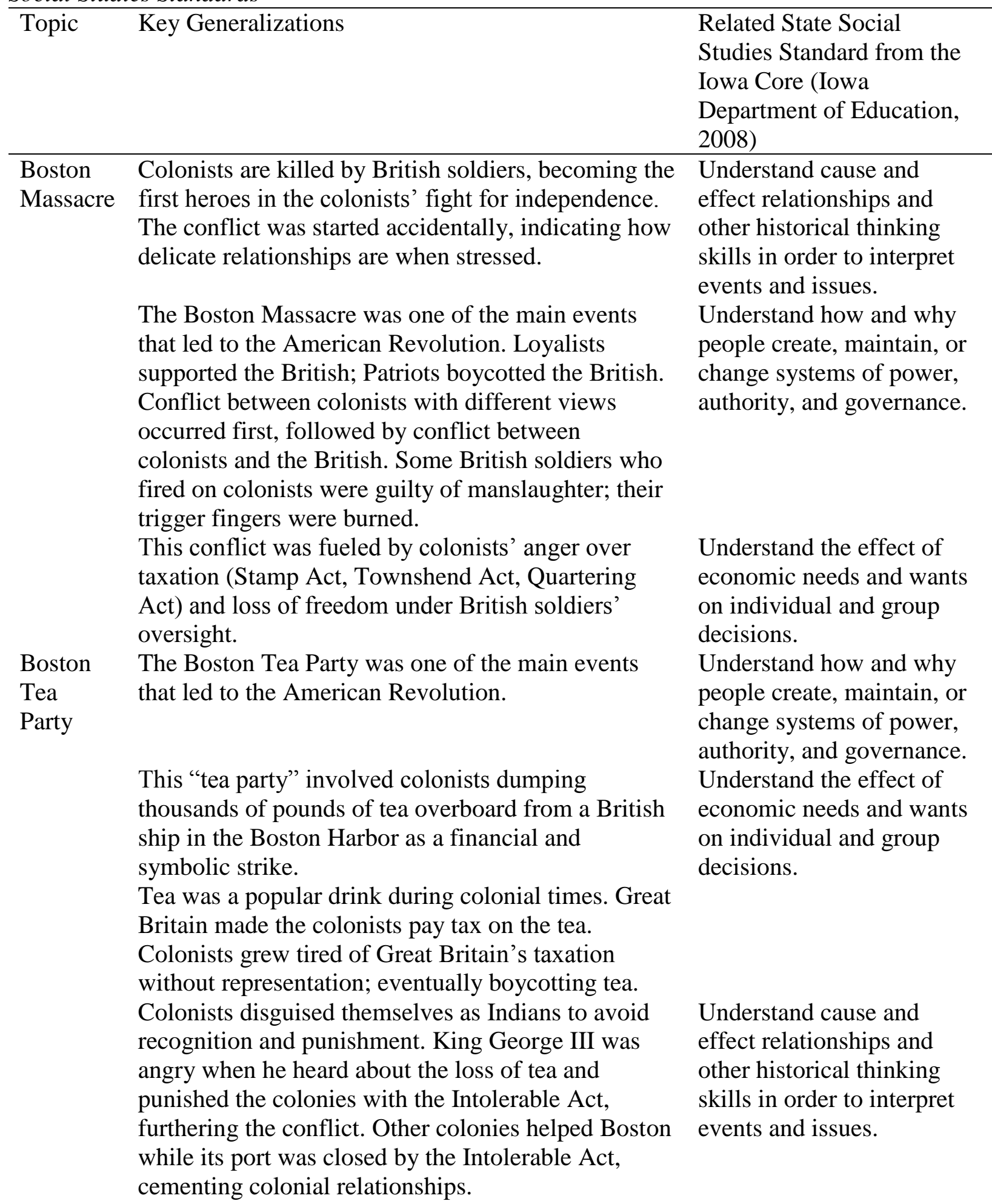




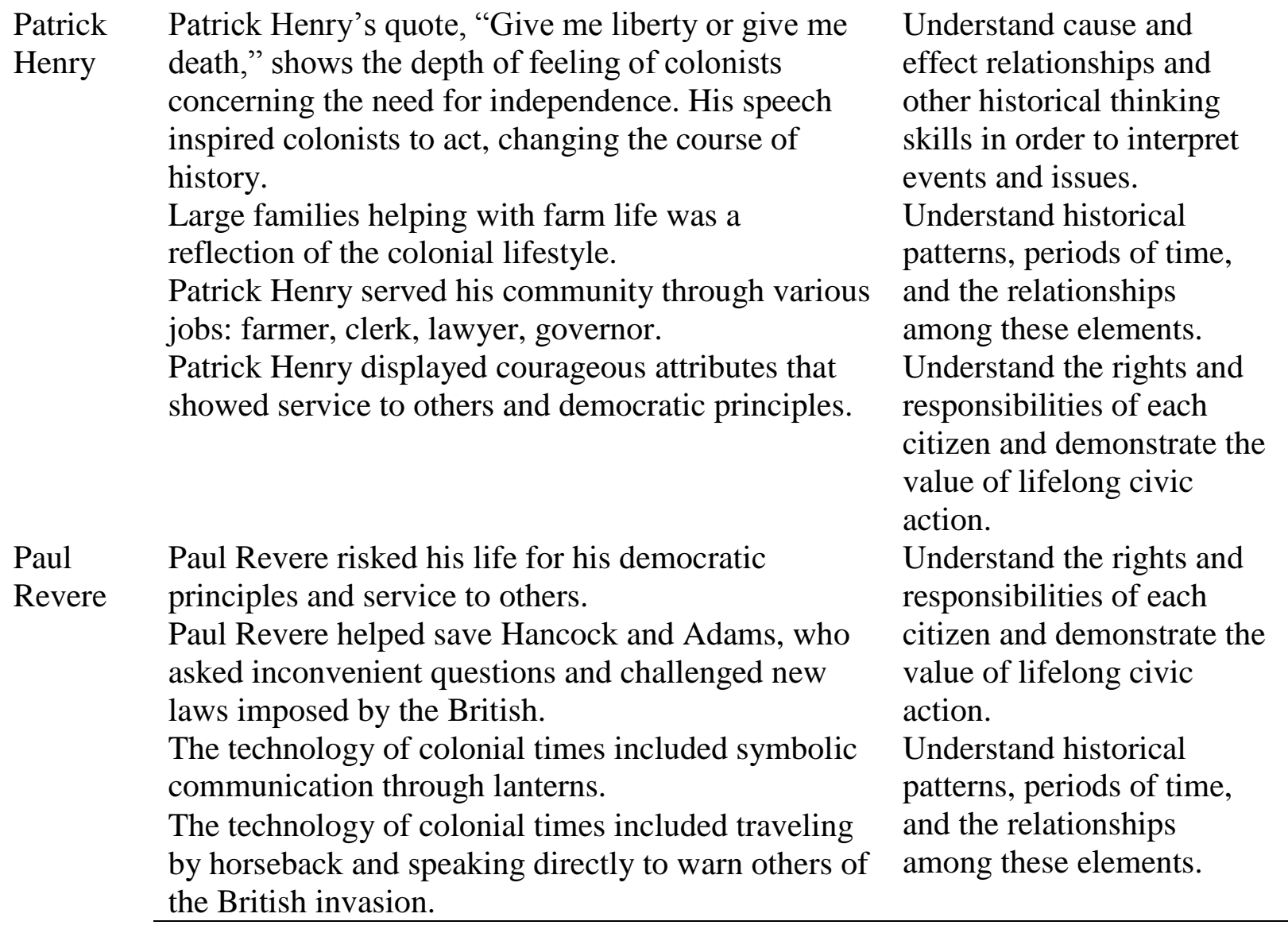

\section{Method}

Twenty-two 5th graders (13 female, 9 male; 21 Caucasian, 1 African American; 20 Native English speakers, 2 English language learners) from a middle-class, suburban school in a Midwestern state participated in the study. These students were investigating the American Revolution in social studies class. The participants included two students with learning disabilities and several low-achieving students who were struggling readers. All students and their parents gave permission for data to be collected and used in this research study, which was approved by the second author's university human subjects review board.

For instruction, students were divided into four groups of five or six students. Each small group read one book on each of the four chosen social studies topics related to the American Revolution. Students in two of the small groups read about the Boston Massacre and Patrick Henry through graphic novels and read about Paul Revere and the Boston Tea Party with illustrated nonfiction texts. Students in the other two small groups read about Paul Revere and Boston Tea Party through graphic novels and read about the Boston Massacre and Patrick Henry through illustrated nonfiction texts.

Each small group met daily for four consecutive days with the school's librarian for about 40 minutes. The school librarian showed students the book cover and asked for ideas of how this topic might be related to the American Revolution. Although this topic had not yet been formally addressed in the students' current classroom instruction, it was the topic of their next 


\section{Social Studies Research and Practice}

www.socstrp.org

unit, which began after the posttest of the current study. These lessons purposely were isolated from other instruction so that student learning shown on the post-test assessment could be attributed to the treatment of reading books under one of the two conditions of this study. Students generally recognized the name of Paul Revere, associating it with his famous ride but could not recall other details of his life or explain the significance of his role in American history. They similarly had heard of the Boston Tea Party as a key event in the American Revolution, but could not explain what happened. Students were unfamiliar with Patrick Henry and the Boston massacre. After students had expressed their prior knowledge, they took a picture walk through the book and spent some initial time exploring its content and hypothesizing what the story entailed. Following the picture walk activity, a student volunteered to read a passage, followed by group discussion of its content. After the entire book had been read in this fashion, the group listed the key ideas from the reading on a piece of chart paper. The school librarian made sure that the key concepts she had previously identified were discussed and listed among those on the chart.

Four illustrated nonfiction prose texts (Draper, 2001a, 2001b, 2001c; Gillis, 2005) that focused on the four topic areas were used for the illustrated nonfiction condition. The Allison Draper books had a color partial-page illustration approximately every other page, while the Jennifer Gillis book had a small illustration on every page. Library Media Connection recommended three, of these books, while Horn Book, providing a fair match for the graphic novels, recommended the fourth. The graphic novels used in this study (Burgan, 2006; Doeden, 2005; Glaser, 2006; Niz, 2006) were from a Capstone Press series called Graphic History, listed in a suggested graphic novel booklist in David Serchay's (2008) Librarian's Guide to Graphic Novels for Children and Tweens. They had large page-sized and half-page-sized color illustrations throughout with no text without illustration.

At the end of each instructional session, students completed two rating scales in which they circled a number from one to ten ("one" meaning least enjoyable or interesting and "ten" indicating most enjoyable or interesting) to indicate their enjoyment of reading this particular book and their interest in the topic. Two weeks later, each student was given a post-test with four questions that asked the student to "Tell five important things you remember about (each of the four topics were put here, in turn, forming the four questions of the assessment)." Students had twenty minutes to complete the posttest.

Student responses to the two rating scales were compiled with the mean and standard deviations calculated. Student posttest responses were compiled for the topics under each condition and reported in order of most to least frequently occurring. Mean numbers of correct responses were tabulated for students under each condition. Paired $t$ test results and a common measure of effect size, Cohen's $d$ (Cohen, 1988) were used to determine statistical and practical significance.

\section{Results}

Table 2 shows the results of the statistical analysis of the collected data. Tables 3 and 4 provide the social studies concepts and generalizations given by students after reading about the four topics under different conditions. 


\section{Social Studies Research and Practice}

www.socstrp.org

Table 2

Comparison of Student Performance, Reported Enjoyment, and Reported Interest under the Two Study Conditions

\begin{tabular}{|c|c|c|c|c|}
\hline & $\begin{array}{c}\text { Illustrated } \\
\text { Nonfiction } \\
\text { Condition } \\
\end{array}$ & $\begin{array}{l}\text { Graphic Novel } \\
\text { Condition }\end{array}$ & $\begin{array}{l}\text { Paired T-Test } \\
\text { Results }\end{array}$ & $\begin{array}{c}\text { Cohen's } d \text { Effect } \\
\text { Size }\end{array}$ \\
\hline $\begin{array}{l}\text { Mean number of } \\
\text { correct ideas } \\
\text { recalled two } \\
\text { weeks after } \\
\text { reading two } \\
\text { books }\end{array}$ & $7.1(3.2)$ & $8.6(2.9)$ & $\begin{array}{l}\quad p<0.01 \\
\text { Statistically } \\
\text { significant }\end{array}$ & $\begin{array}{c}d=0.49 \\
\text { Medium effect } \\
\text { size }\end{array}$ \\
\hline $\begin{array}{l}\text { Mean reported } \\
\text { level of } \\
\text { enjoyment on a } \\
\text { scale of } 1-10 \\
\text { (low to high) }\end{array}$ & $7.6(2.0)$ & $8.3(1.7)$ & $\begin{array}{l}\quad p=0.05 \\
\text { Statistically } \\
\text { significant }\end{array}$ & $\begin{array}{c}d=0.35 \\
\text { Small to } \\
\text { medium effect } \\
\text { size }\end{array}$ \\
\hline $\begin{array}{l}\text { Mean reported } \\
\text { level of interest } \\
\text { on a scale of } 1- \\
10 \text { (low to high) }\end{array}$ & $7.7(2.3)$ & $8.0(2.2)$ & $\begin{array}{c}\quad p=0.15 \\
\text { Not statistically } \\
\text { significant }\end{array}$ & Not calculated \\
\hline
\end{tabular}

Note: Standard deviations in parentheses and effect size interpretation according to Cohen (1988). 


\section{Social Studies Research and Practice}

www.socstrp.org

Table 3

Comparison of Relative Frequency of Types (most frequently cited facts listed first) of

Information Remembered by Students under Different Conditions for Boston Massacre and

Boston Tea Party books

Topic Facts recalled by students in order of most to least frequent Graphic Novel Condition

Illustrated Nonfiction Condition

\begin{tabular}{|c|c|c|}
\hline \multirow{12}{*}{$\begin{array}{l}\text { Boston } \\
\text { Massacre }\end{array}$} & Several colonists killed & Several colonists killed \\
\hline & Eleven-year-old boy killed & Started accidentally \\
\hline & British fired on colonists & Eleven-year-old boy killed \\
\hline & Started accidentally & Led to American Revolution \\
\hline & British called Redcoats, Lobsterbacks & Occurred on a corner in Boston \\
\hline & Led to American Revolution & Ten or twelve shots fired \\
\hline & Marked soldiers by burning thumb & $\begin{array}{l}\text { Some people were wounded but not } \\
\text { killed }\end{array}$ \\
\hline & Jailed soldiers for manslaughter & British called Redcoats, Lobsterbacks \\
\hline & Colonists angry about tea tax & $\begin{array}{l}\text { There were fights between colonists and } \\
\text { British }\end{array}$ \\
\hline & Unknown who fired first shot & Date March 5, 1770 \\
\hline & Told names of participants & \\
\hline & Loyalists were loyal to British & \\
\hline \multirow{15}{*}{$\begin{array}{l}\text { Boston } \\
\text { Tea Party }\end{array}$} & Colonists dumped tea overboard into & Colonists disguised themselves as \\
\hline & the harbor & Mohawk Indians \\
\hline & Colonists disguised themselves as & Colonists dumped tea overboard into \\
\hline & Colonists were angry about the tea tax & Colonists were angry about the tea tax \\
\hline & Led to American Revolution & $\begin{array}{l}\text { Ninety-thousand pounds of tea in } 342 \\
\text { crates was dumped }\end{array}$ \\
\hline & Occurred at night in Boston Harbor & Date December 16,1773 \\
\hline & Colonists boycotted buying tea & Occurred in Boston \\
\hline & Colonists loved drinking tea & Led to American Revolution \\
\hline & $\begin{array}{l}\text { The British king was angry and } \\
\text { punished the colonies }\end{array}$ & $\begin{array}{l}\text { Afterward, colonists drank coffee } \\
\text { instead }\end{array}$ \\
\hline & "No taxation without representation" & Not really a tea party \\
\hline & $\begin{array}{l}\text { Ninety-thousand pounds of tea in } 342 \\
\text { crates was dumped }\end{array}$ & \\
\hline & Date December 16, 1773 & \\
\hline & Colonists swept the decks of the ship to & \\
\hline & & \\
\hline & $\begin{array}{l}\text { British were surprised and did not try to } \\
\text { stop it }\end{array}$ & \\
\hline
\end{tabular}




\section{Table 4}

Comparison of Relative Frequency (most frequently cited facts listed first) of Types of

Information Remembered by Students under Different Conditions for Books about Patrick Henry and Paul Revere

\begin{tabular}{|c|c|c|}
\hline \multirow[t]{2}{*}{ Topic } & \multicolumn{2}{|c|}{ Facts recalled by students in order of most to least frequent } \\
\hline & Graphic Novel Condition & Illustrated Nonfiction Condition \\
\hline \multirow[t]{11}{*}{$\begin{array}{l}\text { Patrick } \\
\text { Henry }\end{array}$} & $\begin{array}{l}\text { Quote "Give me liberty or give me } \\
\text { death" }\end{array}$ & He had 2 wives and 17 total children \\
\hline & He had 2 wives and 17 total children & Fought for American independence \\
\hline & $\begin{array}{l}\text { Brave, smart, stood up for himself and } \\
\text { others }\end{array}$ & Patrick Henry was a lawyer \\
\hline & Patrick Henry was a lawyer & Colonist from Virginia \\
\hline & $\begin{array}{l}\text { Patrick Henry became governor of } \\
\text { Virginia }\end{array}$ & $\begin{array}{l}\text { Quote "Give me liberty or give me } \\
\text { death" }\end{array}$ \\
\hline & $\begin{array}{l}\text { Washington offered him political } \\
\text { offices that he refused }\end{array}$ & Quit school at age 10 \\
\hline & He had jobs as clerk and farmer & Played violin \\
\hline & Lived during revolutionary war & House is a museum now. \\
\hline & & $\begin{array}{l}\text { Patrick Henry became governor of } \\
\text { Virginia }\end{array}$ \\
\hline & & $\begin{array}{l}\text { Quote: "No taxation without } \\
\text { representation" }\end{array}$ \\
\hline & & Died on June 6 \\
\hline \multirow[t]{11}{*}{$\begin{array}{l}\text { Paul } \\
\text { Revere }\end{array}$} & $\begin{array}{l}\text { Captured by Redcoats and horse taken } \\
\text { away }\end{array}$ & $\begin{array}{l}\text { Lantern signal in church about British } \\
\text { invasion: "One if by land; two if by } \\
\text { sea" }\end{array}$ \\
\hline & $\begin{array}{l}\text { Lantern signal in church about British } \\
\text { invasion: "One if by land; two if by } \\
\text { sea." }\end{array}$ & Midnight ride on horseback \\
\hline & $\begin{array}{l}\text { Said, "The British are coming," to warn } \\
\text { people }\end{array}$ & Captured by British. \\
\hline & $\begin{array}{l}\text { Midnight ride on horseback Lexington } \\
\text { to Concord }\end{array}$ & $\begin{array}{l}\text { Said, "The British are coming," to warn } \\
\text { people }\end{array}$ \\
\hline & Saved Hancock and Adams & British let him go \\
\hline & $\begin{array}{l}\text { Gunshot frightened British and they let } \\
\text { him go. }\end{array}$ & Saved Hancock and Adams \\
\hline & He was a colonial silversmith & He rowed past a warship in a boat. \\
\hline & He rowed past a warship in a boat & He wore a hat \\
\hline & & He watched guard for the Boston Tea \\
\hline & & Party \\
\hline & & He was a silversmith \\
\hline
\end{tabular}




\section{Analysis \\ Greater Recall of Issues Related to Complex Events}

The mean number of student-recalled ideas reported in Table 2 shows students were able to recall significantly more concepts and generalizations when reading graphic novels as compared to nonfiction prose. This finding had a medium effect size, indicating that, beyond statistical significance, there was a noticeable practical effect in using graphic novels to teach students concepts and generalizations about the American Revolution. In general, students recalled similar information from the two different genres. A comparison of the key generalizations that the school librarian wanted students to acquire (Table 1) with the information reported by students two weeks after reading books under the two conditions (Tables 3 and 4) showed that students met most expectations under both conditions, but that the graphic novel condition was superior in helping students recall more issues related to complex events.

Specifically concerning the Boston Massacre, students under both conditions did recognize the cause and effect significance of the event to the American Revolution, the accidental and explosive nature of the conflict, and the tragic loss of lives, including the death of an eleven-year-old boy. These ideas addressed several key generalizations planned for students and the social studies standards of the state in which the study occurred. Students, in the nonfiction prose condition, neglected however to mention two key ideas that were discussed by students who read graphic novels, indicating that students reading graphic novels retained more key ideas. These concepts were: (1) the frustration of over-taxed colonists under British authority when their everyday necessities were becoming economically out of reach; and (2) the difference between loyalists and patriots.

Regarding the Boston Tea Party, students under both conditions were able to describe the nature of the event including colonists disguising themselves as Native Americans and dumping tremendous amounts of British tea into the harbor, their dislike of the increased tax burden on tea, and its impact on the American Revolution. Students reading the nonfiction prose did not mention the colonists' love of tea, boycotting of tea, or King George's revenge upon the colonists, while those reading the graphic novels did, implying the efficacy of the graphic novel condition.

Students in both conditions evidenced understanding of major ideas concerning Patrick Henry's famous speech ("give me liberty or give me death") that showed his courage and commitment to democratic principles and how these words inspired colonists to fight for their independence. They also recognized the large-family colonial lifestyle and Patrick Henry's lifelong service to his community including work as a lawyer and governor. Similarly, students under both conditions were able to describe Paul Revere's role in warning people of the British invasion and saving other key colonists, Hancock and Adams. They mentioned the colonial technology of using lanterns as signals and traveling on horseback to verbally warn colonists. There was little difference in topics of the recalled facts between the two conditions concerning biographies of important colonists. As mentioned previously, there were several key ideas related to the complex events of the Boston Massacre and Tea Party that were noted by students reading graphic novels but not reported by students reading nonfiction prose. This may indicate that more complex issues are better understood with the multimodal input afforded by graphic novels. Readers of graphic novels have been found to be adept at using the multimodality of text and graphics to obtain greater meaning for critical inquiry (Schwartz \& Rubinstein-Ávila, 2006). 


\section{Social Studies Research and Practice}

www.socstrp.org

\section{Greater Student Reading Enjoyment}

After each reading lesson, students rated their enjoyment and interest in the text on a scale of one to ten. Table 2 shows that both enjoyment and interest were higher for the graphic novel condition, but only enjoyment evidenced a statistically significant difference. Students' reported enjoyment of reading graphic novels had a small to medium effect size, indicating the practical impact of student motivation supported by reading enjoyment. This finding builds on the one existing study available for the emerging field of graphic novel use in schools. Another study (Edwards, 2008, 2009) examined seventh graders' motivation for reading graphic novels in an eight-week study that examined student vocabulary development, reading comprehension, and motivation toward reading. Although her results did not show statistical significance, all three areas showed improvement for the graphic novel condition. Student ratings for graphic novels were higher and they reported spending more time in free-choice reading of this genre. Our current study with fifth graders showed a positive, but statistically insignificant trend for student interest being increased with use of graphic novels. A larger sample size in a future study may yield significant results in this area also.

Spontaneous student comments to the school librarian during and after the reading of graphic novels revealed student preferences and reasoning. Many students commented that they enjoyed the graphic novel format because the illustrations helped them to see whether or not they were on the right track with their ideas and the meaning they were making from the text. Students' moods were more upbeat when reading graphic novels and they shared more information they were gleaning from the illustrations as they read. They were a more talkative about the graphic novels than the regular nonfiction books and more willing to ask questions about what didn't make sense when reading the graphic novels. The students preferred a lot of illustrations, remarking on the appeal of visual learning in contrast to reading plain text. Their own free-choice reading at home was often comic books; this matched their visual learning style. The facial expressions in illustrations helped them obtain more subtle meanings from the stories and insights into characters. Students enjoyed the novelty of being able to read a graphic novel to learn about history rather than always relying on a textbook. Several commented that they wished they could read more graphic novels in place of the textbook or typical novels. The school librarian observed that students asked about and checked out more graphic novels during library time after this classroom exposure to the genre.

The librarian noted several observations that reinforced the positive findings of graphic novel use. Regarding gender differences concerning the graphic novels, the librarian observed that the boys were more excited to read the graphic novels than the girls at first, but by the conclusion of the graphic novel, the excitement was mutual. The boys were observed to spend more time looking at the pictures in the graphic novels than the girls did. The girls voiced more observations of the pictures in the graphic novels such as comments about the facial expressions of the characters and the type of text in the speech bubbles (sometimes the text was in all caps, different colored text, or some speech bubbles were bolder than others). The girls enjoyed animating their voices as they read the graphic novels to match the character and text.

On the lesson days that struggling readers used the graphic novels, these students immediately opened the books and began looking at the pictures. They were excited to see what kind of story the pictures would present to them and what they could figure out about the topic before the group began reading. When given the nonfiction books, their first response was to flip 


\section{Social Studies Research and Practice}

www.socstrp.org

to the end of the book to see how many pages were in it to gauge how much effort they would have to expend.

The two students who had identified learning disabilities were excited to use a book that wasn't so text heavy; the graphic novel format was definitely a motivator for them. They made comments about how they understood this text format better than the one used in their textbooks and that they learned more from this format--it was easier to follow and understand. These students were also more motivated to read in front of their classmates when using the graphic novels compared to the regular nonfiction books.

\section{Factors that Affected Outcomes of the Study}

A school librarian, who was interested in using graphic novels to teach social studies content, initiated this action research study. She encountered teacher skepticism toward using this genre to teach academic concepts. The librarian wanted to determine if graphic novels could both motivate students and assist them in understanding social studies content addressing the events of the American Revolution. Although the sample size was small, the counterbalanced design of the study allowed students to experience both graphic novels and illustrated informational texts, thereby controlling for the effects of different participants and instructors by having the same participants experience both conditions with the same enthusiastic librarian. The different historic concepts addressed by each of the four trials allowed the effects of each trial to be distinguished.

Some variables that could impact results among and across groups include the social studies or other topics chosen, the quality of the books used, the mix of individual students (abilities, interests, prior experiences, socio-economic status) and the experience or enthusiasm of the teacher. The researchers were able to find quality books about the American Revolution for both genres used in this study; some other topics, however, may not yet have well-designed graphic novels available. The participants of the current study, though showing diversity in reading performance and English-speaking ability, were mostly White middle class children; the outcomes cannot necessarily be generalized to different socio-economic or racial groups.

\section{Conclusions}

Classroom teachers at the school where this study was conducted mentioned they were reluctant to have students read graphic novels because they didn't think they would retain as much factual information from reading. They believed that students would "fly" through the novels without thinking about the implications of what they were reading because students' focus would largely be on the exciting, action-packed graphic illustrations. This sentiment is widespread. "Graphic novels' potential has yet to be acknowledged in many American classrooms" (Carter, 2007, p. 49). Hopefully, our small study showing students learned more from reading graphic novels will encourage teachers to test out the use of graphic novels in their classrooms.

Teachers should be made aware of how graphic novels can be used to meet state standards (Rudiger \& Schliesman, 2007). The students in our study who read graphic novels met state standards (as listed in Table 1) and evidenced understanding of the key generalizations we had identified for this social studies unit introduction. Adam Martin (2009) explained that student understanding of abstract concepts could be facilitated by use of visuals in graphic novels, as most students automatically used images to navigate their everyday lives. "Growing 
up with television and video games, contemporary young adults look for print media that contain the same visual impact and pared-down writing style and contribute to their enthusiasm for visual rather than written literacy" (Bucher \& Manning, 2004, p. 67). Our study indicated that students may have better understood abstract, complex events when presented through the graphic novel format.

Many students expect painful, boring reading experiences in content areas; as we have shown, graphic novels can improve student enjoyment (Versacum 2001). Readers make emotional connections to characters in graphic novels that make the stories more compelling (O'English et al., 2006). Our students remarked on their attraction to the illustrations of character faces expressing the emotions of the story. Students, especially boys, prefer to read items that relate to their interests that they can talk about with friends (Newkirk, 2002). The comic book format and action-oriented illustrations meet that need. The results of our study, combined with other indications from the professional literature, point to the strong potential for graphic novels to positively impact social studies content area instruction.

\section{Ways to Integrate Graphic Novels into Instruction}

Graphic novels may be used to differentiate instruction by providing alternate forms of texts that address the same topic. Students additionally might practice and improve their thinking skills by comparing similar topics in two genres. As shown in this action research study, graphic novels motivated at-risk, reluctant, or struggling students by providing multiple modalities for obtaining meaning. Graphic novels can be used to build visual literacy by having students focus on the implications of various aspects of the images including facial expressions, actions, relative proportions and foreshortening, shading, textures and suggested parts (hazy or incomplete objects or figures). Graphic novel illustrations also may provide comic relief and classroom humor, reducing, for some students, the stresses of reading.

Graphic novels focused on social studies topics can be included as book choices for literature circles and can be used in place of the traditional textbook for many social studies topics. These novels might be checked-out from the library by students to read for pleasure and enjoyment during the classes' free reading time. Graphic novels can be featured during nonfiction read alouds; in a technologically-equipped classroom, a document camera can project the cartoon images on a screen so that the audience can both see and hear the action.

Another way graphic novels may be integrated into classroom instruction is to use them during the idea-finding phase of a student research project. Although graphic novels are not a primary research source, they are useful in stimulating students' ideas about selecting an appropriate research topic. Library information literacy instruction begins with students' inquiry into a focus area of their choosing within the topic studied in class. Students, for example, studying the Oregon Trail could read the Oregon Trail graphic novel (Dunn, 2009). The book includes detailed text in speech bubbles that introduces students to numerous potential research topics that students may choose to investigate further using library resources. For instance, an illustration and text mentions President Jefferson finalizing the Louisiana Purchase in 1803, another shows Jefferson assigning Lewis and Clark an expedition in 1804, and another shows Sacagawea in 1806. Students could engage in inquiry learning using materials about Lewis and Clark, Sacagawea, the Louisiana Purchase, and other issues surrounding these events.

Graphic novels might also be used as a model for students to create their own short graphic novelettes of a scene from history, a current event, or another culture. Perhaps students 


\section{Social Studies Research and Practice}

www.socstrp.org

may work as a small group with one or two students planning the scenes and dialog while a couple of others draw and color the illustrations. Students might do this manually, tracing parts of characters from other graphic novels to assist them in drawing them to show perspective and foreshortening; or electronically, using clip art and talking balloons, or modifying imported Internet images to suit their needs.

Because of our success in using graphic novels for reading about and learning concepts and generalizations related to the American Revolution in the content area of social studies, we recommend the following practices.

First, teachers should seek to collaborate with librarians to introduce new genres like graphic novels to enliven and enrich content area reading. In our study, the school librarian initiated contact with fifth grade teachers after purchasing a graphic novel series for the school library. Professional librarians can use an online source to evaluate and recommend graphic novels for school or public library purchase. The Graphic Novels Core Collection, first published by H. W. Wilson in 2007, is available through an online subscription. It supplements other H. W. Wilson tools (such as Senior High Core Collection, Children's Core Collection, and Fiction Core Collection) librarians use to select the highest quality library resources. Graphic Novels Core Collection includes descriptive and evaluative annotations of all types of graphic novels and has excerpts from reviews, awards notes, and ratings of age appropriateness. Several websites offer useful information about graphic novels. Wikipedia (2011) provides a list of awards for graphic novels and recent recipients. Comic-Com (2004-2011) records the winners of the comic industry's own Eisner Awards. Additionally, the American Library Association (2011) and a consortium of universities, ipl2: Information You Can Trust (2011), provide lists of graphic novels recommended for teens.

Second, school librarians can highlight new books through displays, book talks, reading clubs, informal conversations, and "spotlights" at faculty meetings.

Third, teachers should request that both school and public libraries develop collections of high quality fiction and nonfiction graphic novels to supplement content area teaching and meet the varied interests of young people. Our study indicated that students experienced more enjoyment when reading graphic novels, boosting their motivation for reading.

Fourth, the research base on use of graphic novels in content area reading is almost nonexistent. More studies defining the efficacy and best instruction practices of this genre in helping students learn content information is needed.

\section{References}

Bednarz, S., Clinton, C., Hartoonian, M., Hernandez, A., Marshall, P. L., \& Nickell, P. (1997). We the people. Build our nation. Boston, MA: Houghton Mifflin.

Bruggeman, L. (1997). 'Zap! Whoosh! Kerplow!: Build high-quality graphic novel collections with impact. School Library Journal, 43(1), 22-27.

Bucher, K. T., \& Manning, M. K. (2004). Bringing graphic novels into a school's curriculum. Clearinghouse, 78(2), 67-72.

Burgan, M., Wiacek, B., Williams, K., \& Barnett, C. (2006). The Boston Massacre. Mankato, MN: Capstone Press. 


\section{Social Studies Research and Practice}

www.socstrp.org

Carrington, V. (2004). Texts and literacies of the Shi Jinrui. British Journal of Sociology of Education, 25(2), 215-228.

Carter, J. B. (2007). Transforming English with graphic novels: Moving toward our "Optimus Prime". English Journal, 97 (2), 49-53.

Cohen, J. (1988). Statistical power analysis for the behavioral sciences (2nd ed.). Hillsdale, NJ: Lawrence Erlbaum Associates.

Doeden, M., Barnett, C., \& Hoover, D. (2005). The Boston Tea Party. Mankato, MN: Capstone Press.

Draper, A. S. (2000). The Boston Tea Party: Angry colonists dump British tea. New York, NY: PowerKids Press.

Draper, A. S. (2001). The Boston Massacre: Five colonists killed by British soldiers. New York, NY: PowerKids Press.

Draper, A. S. (2001). The start of the American Revolutionary War: Paul Revere rides at midnight. New York, NY: Powerkids Press.

Dunn, J. W. (2009). The Oregon Trail. Graphic History. Edina, MN: Graphic Planet.

Edwards, B. (2009). Motivating middle school learners: The graphic novel link. School Library Media Activities Monthly, 25(8), 56-58.

Edwards, B. (2008). Motivation and middle school readers: Graphic novels, comic books, and free voluntary reading time. Ph.D. diss., University of Oklahoma.

Gillis, J. B. (2005). Patrick Henry. Chicago, IL: Heinemann Library.

Glaser, J., \& McDonnell, P. (2006). Patrick Henry: Liberty or death. Mankato, MN: Capstone Press.

Gorman, M. (2008). A new generation of graphic novels: Expect the unexpected. Library Media Connection, 26(6), 38.

Griffith, P. E. (2010). Graphic novels in the secondary classroom and school libraries. Journal of Adolescent and Adult Literacy, 54(3), 181-189.

Lavin, M.R. (1998). Comic books and graphic novels for libraries: What to buy. Serials Review, 24(2), 31-46.

Lyga, A.W., and Lyga, B. (2004). Graphic novels in your media center: A definitive guide. Westport, CN: Libraries Unlimited.

MacDonald, H. (2004). Drawing a crowd: Graphic novels are a great way to generate excitement. School Library Journal,50(8), 20-22.

Martin, A. (2009). Graphic novels in the classroom. Library Media Connection, 28(2), 30-31.

McCloud, S. (1998). New adventures of Abraham Lincoln. Berkeley, CA: Image Comics.

McLuhan, M. (1964). Understanding media: The extensions of man. New York, NY: McGrawHill.

Newkirk, T. (2002). Forward to Michael W. Smith and Jeffrey D. Wilheim. Reading don't fix no Chevys: Literacy in the lives of young men. Portsmouth, NH: Heinemann.

Niz, X., \& Bascle, B. (2006). Paul Revere's ride. Mankato, MN: Capstone Press.

O’English, L. Matthews, J. G., \& Lindsay, E. B. (2006). Graphic novels in academic libraries: From Maus to manga and beyond. The Journal of Academic Librarianship, 32(2), 173182.

Rudiger, H. M., \& Schliesman, M. (2007). Graphic novels and school libraries. Knowledge Quest, 36(2), 57-59. 


\section{Social Studies Research and Practice}

www.socstrp.org

Schwarz, G. E. (2002). Graphic novels for multiple literacies. Journal of Adolescent and Adult Literacy, 46(3), 262-265.

Schwartz, A., \& Rubinstein-Ávila, E. (2006). Understanding the manga hype: Uncovering the multimodality of comic-book literacies. Journal of Adolescent and Adult Literacy, 50(1), 40-49.

Serchay, D. S. (2008). Graphic novels for children and tweens. New York, NY: Neal-Shuman.

Seyfried, J. (2008). Reinventing the book club: Graphic novels as educational heavyweights. Knowledge Quest, 36(3) 44-48.

Short, J. C., \& Reeves, T. C. (2009). The graphic novel: A "cool" format for communicating to Generation Y. Business Communication Quarterly, 72(4), 414-430.

Simmons, M., \& O’Bryant, B. (2009). Journey into the world of manga and graphic novels. Library Media Connection, 27(4), 16-17.

Sunal, C. S., \& Haas, M. E. (2011). Social studies for the elementary and middle grades: A constructivist approach (4th ed.). Boston, MA: Pearson.

Versaci, R. (2001). How comic books can change the way our students see literature: One teacher's perspective. English Journal, 91(2), 61-6

\section{Web-Based References}

American Library Association. (2011). Young adult library services association: Great graphic novels for teens. Retrieved from: http://www.ala.org/ala/mgrps/divs/yalsa/booklistsawards/greatgraphicnovelsforteens/gn.c $\mathrm{fm}$

Comic-Com. (2004-2011). Wilson and Dapper Men tie for best graphic album at 2011 Eisner Awards. Retrieved from: http://www.comic-con.org/cci/cci_eisners_11win.php\#list

Iowa Department of Education. (2008). Iowa core: Right work. Right time. Right people. Retrieved from: http://www.corecurriculum.iowa.gov/

ip12: Information You Can Trust. (2011). For Teens: Graphic novels. History and basics; importance of Japanese comics; in schools \& libraries; and webcomics, great links, \& more resources. Retrieved from: http://www.ipl.org/div/graphicnovels/

Wilson, H. W. (2011). Children's core collection (Children's catalog). Online version Wilson Web. Retrieved from: http://www.hwwilson.com/print/childcat.cfm\#Online

Wikipedia. (2011). List of award-winning graphic novels. Retrieved from: http://en.wikipedia.org/wiki/List_of_award-winning_graphic_novels

\section{Authors' Bios}

Kari Bosma is a Teacher Librarian in the Ankeny Community School District, Ankeny, Iowa. Her research interests focus on collaborating with classroom teachers to provide engaging and informative content reading materials, including graphic novels.

Audrey C. Rule is an Associate Professor of Elementary Education in the Department of Curriculum and Instruction at the University of Northern Iowa, Cedar Falls, Iowa. Her research interests include social studies education, curriculum materials development, spatial skills, project based learning, and enrichment/ gifted and talented education. E-mail: audrey.rule@uni.edu 


\section{Social Studies Research and Practice}

www.socstrp.org

Karla S. Krueger is an Assistant Professor of School Library Studies in the Department of Curriculum and Instruction at the University of Northern Iowa, Cedar Falls, Iowa. Her research interests center on school library programs, inquiry learning through research and the influence of school library resources on student learning. 